\title{
Potential seed dispersal by Didelphis albiventris (Marsupialia, Didelphidae) in highly disturbed environment
}

\author{
Mauricio Cantor ${ }^{1,3}$, Letícia Andrade Ferreira ${ }^{2}$, Wesley Rodrigues Silva ${ }^{1}$ \& Eleonore Zulnara Freire Setz ${ }^{1}$ \\ ${ }^{1}$ Departamento de Biologia Animal, Instituto de Biologia, \\ Universidade Estadual de Campinas - UNICAMP, \\ CEP 13083-970, Campinas, SP, Brasil, www.unicamp.br \\ ${ }^{2}$ Instituto de Matemática, Estatística e Computação Científica, \\ Universidade Estadual de Campinas - UNICAMP, \\ CEP 13083-970, Campinas, SP, Brasil, www.unicamp.br \\ ${ }^{3}$ Corresponding author: Mauricio Cantor, e-mail: m.cantor@ymail.com
}

CANTOR, M., FERREIRA, L.A., SILVA, W.R. \& SETZ, E.Z.F. Potential seed dispersal by Didelphis albiventris (Marsupialia, Didelphidae) in highly disturbed environment. Biota Neotrop. 10(2): http://www.biotaneotropica. org.br/v10n2/en/abstract?article+bn00610022010.

\begin{abstract}
Urban forests are usually isolated and highly disturbed, however they are important shelters for tolerant animal species. Their food habits expose the different ecological roles these animals perform in the habitat. We analyzed the contribution of Didelphis albiventris Lund (1840), as a seed disperser, to the vegetation renewal of an urban forest fragment, describing its frugivorous diet and testing the viability of ingested seeds. Both male and female of white-eared opossum included a vast variety of items in their diet, mainly invertebrates and fruits. Fruits were consumed during all year round and seasonality was not observed. The majority of consumed fruits was from pioneer plant species, which is common in disturbed areas, in accordance to the opossum's opportunistic habits. The viability of ingested seeds, evaluated by linear logistic regression models applied to data from germination tests, was different of the seeds collected directly from ripe fruits; it varied among species, maybe due to the intrinsic characteristics of plant species. As a highly generalist species, D. albiventris can inhabit disturbed environments and then disperse seeds from pioneer plants, where the vegetation must be restored. It is crucial that this process does not depend only on the specialist frugivores, which are frequently absent in urban forest fragments. Therefore, the presence of generalist species of secondary environments has its importance emphasized.

Keywords: Didelphimorphia, seed dispersal, seed germination, forest restoration, remnant forest, Didelphis albiventris.
\end{abstract}

CANTOR, M., FERREIRA, L.A., SILVA, W.R \& SETZ, E.Z.F. Potencial dispersão de sementes por Didelphis albiventris (Marsupialia, Didelphidae) em ambiente altamente perturbado. Biota Neotrop. 10(2): http://www. biotaneotropica.org.br/v10n2/pt/abstract?article+bn00610022010.

Resumo: Florestas urbanas são geralmente isoladas e altamente degradadas; contudo são importantes abrigos para espécies de animais tolerantes. Os hábitos alimentares destes animais explicitam os diferentes papéis ecológicos que eles desempenham no hábitat. Nós analisamos a contribuição de Didelphis albiventris Lund (1840) como dispersor de sementes para a regeneração da vegetação de um fragmento florestal urbano. Para isso, descrevemos sua dieta frugívora e testamos a viabilidade das sementes por ele ingeridas. Tanto machos quanto fêmeas de gambáde-orelha-branca incluiram uma grande variedade de itens alimentares na dieta, principalmente invertebrados e frutos. Frutos foram consumidos durante todo o ano e a sazonalidade não foi observada. A maioria das sementes defecadas era proveniente de plantas pioneiras, comuns em ambientes perturbados, o que concorda com seu hábito oportunista. A viabilidade das sementes ingeridas, verificada mediante modelos de regressão logística linear aplicada a dados de testes de germinação, foi diferente das sementes obtidas de frutos maduros e variou entre espécies, talvez devido a características intrínsecas da planta. Enquanto uma espécie generalista, D. albiventris é capaz de habitar ambientes perturbados, e dispersar as sementes de plantas de estágio inicial de sucessão, onde a vegetação necessita ser restaurada. É essencial que este processo não dependa exclusivamente de frugívoros especialistas, que na maioria das vezes estão ausentes nos fragmentos florestais urbanos. Consequentemente, a presença de espécies generalistas de ambientes secundários tem sua importância enfatizada.

Palavras-chave: Didelphimorphia, dispersão de sementes, germinação, restauração florestal, remanescente florestal, Didelphis albiventris. 


\section{Introduction}

Alteration and depletion of natural habitats cause major consequences for biological communities, such as the extinction of species and fragmentation of native vegetation (Shafer 1990). The results of this rough process are small and isolated areas which are often in high level of disturbance. Small reserves continue to provide an important niche in strategies for conservation (Shafer 1990) and the need of their restoration is as great as the protected areas, because they serve as shelter for many species that tolerate human disturbance and have relatively small home ranges (Schelhas \& Greenberg 1996).

South American didelphid marsupials are nocturnal and solitary small mammals whose food habit is often reported as frugivorousomnivorous, consuming invertebrates, small vertebrates and fruits (Emmons \& Feer 1990). As they present a generalist diet and accept a great variability of food items, an opportunistic habit is suggested as general characteristic of the group (Streilein 1982b, Santori et al. 1995, Martins \& Bonato 2004). Although important in intermediate trophic levels as top predator`s prey (Facure \& Giaretta 1996, Aragona \& Setz 2001), these marsupials can also play other ecological roles, acting as predators of vertebrates (e.g. Oliveira \& Santori 1999, Rollins \& Carroll 2001), opportunistic gummivores (Aléssio et al. 2005), pollinators (Steiner 1981) and seed dispersers of the fruits they consume (e.g. Atramentowicz 1988, Cáceres et al. 2002, Cáceres 2004).

Seed dispersal is the result of mutualistic interaction between plants and animals that eat fleshy and nutritive fruits, which contain from one to several seeds (Van der Pijl 1982). The reward for the plant is the fitness increase, either by removing seeds from the environment of high mortality to which they are exposed near the parent plant - due to the high competition for local resources and intense predation by insects and rodents (Janzen 1970, Connell 1971, Howe et al. 1985) - and the conquest of new environments conducive to germination (Fleming \& Sosa, 1994, Howe 1993). In a broader view, multispecific networks can be drawn using this interaction, in which large assemblages of specialists and generalists - plants and animals - have been co-evolutionarily molded through time, and whose implications for the persistence of biodiversity have been recently addressed (for a review, see Bascompte \& Jordano 2007).

The white-eared opossum, Didelphis albiventris Lund (1840), is a widespread opossum which occupies a broad niche and is found in a continuous set of open and deciduous forest formations (Cerqueira 1985), from Colombia to central Argentina (Emmons \& Feer 1990). Urban areas and disturbed environments are also frequent habitats of this marsupial (Fonseca et al. 1982). In these habitats, where forest regeneration is especially required, this didelphid may play a significant role in the reforestation process, by dispersing the seeds of the consumed fruits.

In order to test the hypothesis of $D$. albiventris participating in the seed dispersal of disturbed environments, we performed an experiment to investigate its frugivorous diet and the germination probability of consumed seeds from an urban forest fragment. We, therefore, addressed the following questions: 1) which plant species from a highly disturbed area does the opossum include in its diet? 2) For each plant species, is the germination success of ingested seeds similar to the non-ingested seeds? and 3) Which is its' contribution as a seed disperser in small urban fragments?

\section{Material and Methods}

\section{Study area}

The study area covered the Ecologic Park Professor Hermógenes de Freitas Leitão Filho (13.44 ha) and includes a 1.24 ha secondary swamp forest fragment around an artificial dam, in a region of tropical seasonal semideciduous forest. It is located in Campinas city, SP, in Southeastern Brazil. There are two slightly defined seasons: one is a little colder and dry (from April to September) and the other, hotter and wet (from October to March) (CEPAGRI 2009).

\section{Sampling design and data collection}

We sampled the marsupials along a $1600 \mathrm{~m}$ transect around the dam, using a set of 100 Young live traps $(40 \times 20 \times 20 \mathrm{~cm})$, with the bottom covered with cardboard to collect the scats. Every $40 \mathrm{~m}$ there was a trap on the floor and one in understory (1.6 to $2 \mathrm{~m}$ high) and, in every $80 \mathrm{~m}$ there was a trap placed in the canopy, about $5 \mathrm{~m}$ above ground. During 12 months (November, 2006 to November, 2007) we performed sampling of 3 consecutive nights per month. We baited the traps with a mass of bananas, cornmeal, peanut butter, vanilla essence and fish liver oil, supported on a slice of manioc. The traps were checked in the morning of the following days and, if necessary, rebaited.

When an animal was caught, we recorded its sex and age, marked with numbered metal ear tags and released in the same location. Individuals with three and four erupted molar teeth were considered adults (modified from Graipel et al. 2006). The fecal samples were collected to infer the diet. They were dissolved in tap water, filtered with a sieve of $1 \mathrm{~mm}$, dried and analyzed with a magnifying glass. We recorded the presence of arthropods (chitin and keratin structures), mollusks (calcareous remains from shells), mammals (hair), birds (feathers and/or beak remains), fishes (scales) and fruits (presence of seeds, fiber and/or peel). Mammal hair was compared with opossum's to ensure that it was not from self-cleaning. Scales were compared with those of reptiles and all of them came from fish.

We washed, counted and identified the seeds, based on the surveys of local flora (Santin 1999, Morita \& Tamashiro, unpublished data) and a reference collection, obtained by monthly collections of fruit of the region. We performed two germination treatments: one with the seeds found in the fecal samples (Fecal Treatment) and another with the seeds from the collection of reference (Control), in a similar number of seeds for each one (sometimes it was hard to find fresh fruits in the park). For each species, we used seeds from more than one ripe fruit, collected preferentially on the ground, but also from the plant. Before the experiment, we treated all the seeds with fungicide Micostatin ${ }^{\circledR}$ and a $4 \%$ solution of Sodium Hypochlorite to avoid fungus attacking the seeds. Seeds were placed in closed Petri dishes containing a humid absorbent paper, and under natural light conditions, simulating a gap in the canopy. We checked the moisture and germination every two days up to a maximum duration of 60 days. We consider a seed germinated when there was protrusion of the hipocotile-radicular axis.

\section{Data analysis}

Differences on diet items between sex and seasons were evaluated applying Chi-square test of homogeneity. Seasonal variation in the number of fruit species consumed by adult individuals was tested by one-way ANOVA on square-root transformed data. Chi-square test of homogeneity was used to verify the proportion of germinated seeds of Control and Fecal Treatments for all seeds together, while Pearson's Chi-square was applied for each species of the five most commonly found in fecal samples.

In order to model the probability of seed germination, we performed a linear logistic regression analysis (Agresti 2002). Since the germination probability could be influenced by the passage through the gut and by the intrinsic characteristics of the plant species, we developed models taking into account the influence of germination treatment and the different seed species. We first built a complete model with 10 parameters, in which Psidium guajava and 
the Control treatment were arbitrarily chosen as references. Among these parameters, one account for the germination probability of the references, while the other parameters considered the effect of the experimental treatments (Fecal Treatment and Control), the effect of plant species (the five most consumed) and the interaction between these two factors. We created other reduced models by removing covariates of the non-significant parameters. The residual test was performed to verify if the chosen model fitted the data. The parameters of the chosen model were therefore estimated and, to achieve a better scaling for interpreting the results, the odds ratios were calculated to estimate the germination probability of a determined seed species under one of the treatments in relation to the other species and treatments. An odd of an event (i.e. seed germination) is the probability of the event occurring divided by the probability that the event does not occur. In this case, it was calculated by the exponent of the parameter estimates.

The analyses were performed using SPSS 13.0, SAS and Minitab software, considering a significance level of 0.05 .

\section{Results}

From a sampling effort of 2,868 trap-nights, 226 captures of Didelphis albiventris, including 57 recaptures, were analyzed (135 females, 65 males), and 222 fecal samples were obtained.

\section{Diet composition}

The diet of the study species was composed mainly of invertebrates (34.9\% Arthropoda; 7.8\% Molusca) and fruits (28.8\%), followed by vertebrates (10.5\% mammal; $10.8 \%$ bird; $7.2 \%$ fish). Males and females showed similar diet composition $\left(\mathrm{x}^{2}=41.39\right.$, $\mathrm{df}=5, \mathrm{p}=0.530$ ). Except for the fruits, adults presented differences on the diet composition between the two seasons $\left(x^{2}=144.916\right.$, $\mathrm{df}=5, \mathrm{p}=0.013)$.

\section{Fruit consumption}

Consumption of 37 species of plants was recorded: seeds from 21 identified different fruits and from nine unidentified fruits, vestiges of four plant species of fruits with large seeds (Table1) and three species of flowers (Inga marginata Willd., Inga fagifolia G. Don and Eucalyptus sp. L'Hér.). The total number of seeds was 3,868 - varying from one to 566 seeds per fecal sample. Seeds length ranged from 0.5 to $13.3 \mathrm{~mm}$. Small seeds were more frequent; some specimens of large seeds $(>6.0 \mathrm{~mm})$ were chewed. During the dry season, 25 fruit species were consumed, while 21 were consumed during the rainy. There was no difference in fruit richness consumption among adult individuals $(\mathrm{F}=0.247, \mathrm{p}=0.621)$. Some species of fruits were consumed during a period of at least eight months (Table 1).

\section{Germination}

Seeds of the five most commonly found plant species in the feces $(n=3,578)$ were utilized in the two treatments of the germination tests (mean \pm SD number of seeds per Petri dish): Morus nigra $\mathrm{L} .(\overline{\mathrm{x}}=67.37 \pm 125.48)$; Psidium guajava $\mathrm{L}$. $(\overline{\mathrm{x}}=13.43 \pm 27.32)$, Piper amalago $\mathrm{L} .(\overline{\mathrm{x}}=15.14 \pm 23.23)$, Passiflora edulis Sims $(\overline{\mathrm{x}}=15.89 \pm 56.5)$ and Cecropia pachystachya Trécul $(\overline{\mathrm{x}}=12.76 \pm 37.74)$.

We applied a reduced linear logistic regression model, by removing two non-significant parameters (increase in log odds by C. pachystachya; and the interaction between $M$. nigra and the germination test treatments). The residual test indicate that this model fitted to the data $\left(\mathrm{x}^{2}=4.58, \mathrm{p}=0.101\right)$.

The proportion of all germinated seeds from Control was different from the proportion of all germinated seeds from Fecal Treatment $\left(\mathrm{x}^{2}=160.28, \mathrm{df}=5, \mathrm{p}<0.001\right)$. Specifically, the trees $C$. pachystachya Trécul $\left(\mathrm{x}^{2}=29.39, \mathrm{p}<0.001\right)$, M. nigra L. $\left(\mathrm{x}^{2}=62.24, \mathrm{p}<0.001\right)$ and P. guajava L. $\left(\mathrm{x}^{2}=145.56, \mathrm{p}<0.001\right)$ presented a 4.84 times higher probability of germination in Control (odds ratio $=4.84$ ). The liana $P$. edulis Sims $\left(\mathrm{x}^{2}=0.07, \mathrm{p}=0.793\right)$ and the shrub $P$. amalago $\mathrm{L}$. $\left(\mathrm{x}^{2}=1.59, \mathrm{p}=0.207\right)$ presented the same proportion of germinated seeds in both tests (Table 2). In Control, C. pachystachya Trécul was the most likely species to germinate, followed by . guajava L., $P$. amalago L. and $M$. nigra L., respectively. In Fecal Treatments, C. pachystachya Trécul and M. nigra L. presented the same probability of germination as $P$. guajava L., which was 21.3 times more than P. edulis Sims and half as likely than P. amalago L. (Table 3).

\section{Discussion}

The food habits of a species can reflect the different ecological roles that it performs in its habitat. The consumption of a wide variety of plant species and the frequent presence of seeds, with some level of germination viability, in the feces of Didelphis albiventris are good indicators of its participation as seed disperser.

The white-eared opossum feeds on fruit in an opportunistic manner (Charles-Dominique et al. 1981, Cáceres \& Monteiro-Filho 2001, Cáceres 2002), using a nomad foraging strategy (Streilein 1982b, Monteiro-Filho 1987). Previous studies pointed out 18 genera and 22 fruit plant species composing the D. albiventris' Lund (1840) diet (see Cáceres 2006). We found vestiges of only seven of those genera, but of at least 16 additional species, which reinforces its generalist feeding habit (Streilein 1982b, Santori et al. 1995, Martins \& Bonato 2004). These habits allow both adults and young to include in their diet those and several other food items according to their availability. Three of the most consumed plant genera by this population are among the five genera considered as omnipresent in first succession stages in Neotropical forests (Piper L., Cecropia Loefl., Solanum L., Trema Lour. and Urera Gaudich.), which also present endozoochorous syndrome (Vázquez-Yanes 1979).

Seasonality in the diet is documented for some marsupial species (Julien-Laferrièrie \& Atramentowicz 1990, Santori et al. 1995, Leiner \& Silva 2007) and D. albiventris as well: arthropods and endotermic vertebrates were more frequently consumed during the dry season while invertebrates, fruits and reptiles were consumed by the young during the rainy season (Streilein 1982a, Cáceres 2002). As the tropical and subtropical forests show seasonal patterns of fructification (Smithe 1970, Charles-Dominique et al. 1981) the same would be expected in fruit consumption (Cáceres et al. 2002). No seasonality in adult frugivory in this population may be due to the continuous fructification of zoochorous plants in our region and due to the prolonged fruiting (between six and eight months) (Table 1) of the most consumed species, except for M. nigra. Morellato (1991), studying 106 species of trees, shrubs and lianas with zoochorous syndrome in the vicinity of our study area, found a non-seasonal pattern of fructification, except for a slight increase of species with fruits in the wetter months.

One important advantage of the frugivory for plants is the increase in seed germination rate (Van der Pijl 1982). High germinability is necessary to maximize the reproductive success and seedling recruitment (Harper 1977). In general, passage through the gut of a vertebrate causes the ingested seeds to germinate in higher number and in less time than non-ingested seeds (Traveset \& Verdú 2002). There are at least three mechanisms responsible for this situation: the removal of pulp that could reduce or prevent germination (Barnea et al. 1991, Meyer \& Witmer 1998); the mechanical or chemical seedcoat scarification in the vertebrate gut; or the consequent fertilization by the fecal matter (Traveset et al. 2001, but see Meyer \& Witmer 
Table 1. Total frequency of fruit consumption in Didelphis albiventris' diet, largest seed size and phenology of plants (period of occurrence of fruits in the study area) based on occurrence of seeds on fecal samples collected between November 2006 and October 2007.

Tabela 1. Frequencia total de consumo de frutos na dieta de Didelphis albiventris, maior comprimento de semente e fenologia das plantas (período de ocorrência dos frutos na área de estudo) baseados na ocorrência de sementes nas amostras de fezes coletadas entre Novembro de 2006 e Outubro de 2007.

\begin{tabular}{|c|c|c|c|c|}
\hline Species & Family & $\begin{array}{c}\text { Frequency } \\
(\%)\end{array}$ & $\begin{array}{c}\text { Seed size } \\
(\mathbf{m m})\end{array}$ & Phenology \\
\hline Morus nigra $\mathrm{L}$. & MORACEAE & 47.21 & 2.0 & Sept.-Oct. \\
\hline Psidium guajava $\mathrm{L}$. & MYRTACEAE & 16.31 & 3.0 & Dec.-Mar, Aug.-Sept. \\
\hline Piper amalago L. & PIPERACEAE & 14.48 & 0.8 & Nov.-May \\
\hline Passiflora edulis Sims ${ }^{1}$ & PASSIFLORACEAE & 10.57 & 6.5 & Jan.-Sept. \\
\hline Cecropia pachystachya Trécul & CECROPIACEAE & 6.95 & 2.0 & Nov.-May \\
\hline Brachiaria decumbens Stapf & POACEAE & 0.88 & 2.6 & Mar-Aug. \\
\hline Solanum sp. L. & SOLANACEAE & 0.39 & 1.6 & Apr.-June \\
\hline Hovenia dulcis Thunb. & RHAMNACEAE & 0.34 & 4.0 & Apr.-June \\
\hline Turnera ulmifolia $\mathrm{L}$. & TURNERACEAE & 0.21 & 2.6 & Feb.-June \\
\hline Leucaena leucocephala (Lam) de $\mathrm{Wit}^{2}$ & FABACEAE & 0.13 & 8.8 & Feb.-June and Nov. \\
\hline Solanum aculeatissimum Jacq. & SOLANACEAE & 0.10 & 1.2 & Nov.-June \\
\hline Amaranthus hybridus L. & AMARANTHACEAE & 0.08 & 1.9 & Feb. and July \\
\hline Cyperus sp. L. & CYPERACEAE & 0.08 & 3.2 & Apr.-Aug. \\
\hline Polygonum sp. L. & POLYGONACEAE & 0.05 & 3.0 & June \\
\hline Stylosanthes sp. Sw. & FABACEAE & 0.05 & 2.1 & June \\
\hline Carica papaya $\mathrm{L}$. & CARICACEAE & 0.03 & 6.0 & June \\
\hline Luziola sp. Juss. & POACEAE & 0.03 & 2.0 & May \\
\hline Paspalum sp. L. & POACEAE & 0.03 & 1.1 & May \\
\hline Sapindus saponaria $\mathrm{L}$. & SAPINDACEAE & 0.03 & 13.3 & Mar \\
\hline Sida sp. L. & MALVACEAE & 0.03 & 2.0 & Aug. \\
\hline Unidentified (9 morphospecies) & - & 1.99 & - & - \\
\hline Eriobotrya japonica (Thunb.) Lindl. ${ }^{3}$ & ROSACEAE & Vestige & 25.0 & May-June \\
\hline Spondias mombin L. ${ }^{3}$ & ANACARDIACEAE & Vestige & 23.0 & Mar \\
\hline Syagrus romanzoffiana (Cham.) Glassman ${ }^{3}$ & ARECACEAE & Vestige & 35.0 & Jan-May \\
\hline Terminalia catappa $\mathrm{L} .{ }^{3}$ & COMBRETACEAE & Vestige & 60.0 & May-June \\
\hline Muntingia calabura L. $^{4}$ & MUNTINGIACEAE & - & 0.5 & Mar \\
\hline
\end{tabular}

${ }^{1}$ Species which seeds were also found chewed; ${ }^{2}$ Probable accidental ingestion, due to the large quantity of seed observed in the ground; ${ }^{3}$ Presence of fiber and peel, but not seeds; ${ }^{4}$ Seeds obtained from intestinal content in necropsy of marked animal that was hit by a car.

${ }^{1}$ Espécies cujas sementes também foram encontradas mastigadas. ${ }^{2}$ Provável ingestão acidental, devido a grande quantidade de sementes observadas no solo da área de estudo; ${ }^{3}$ Presença de fibras e casca, mas não sementes; ${ }^{4}$ Sementes obtidas de conteúdo intestinal a partir de necrópsia de animal marcado e encontrado atropelado.

Table 2. Results of germination tests of the most abundant seeds from fecal samples of Didelphis albiventris (Fecal Treatment) and from fresh fruits collected in the study area (Control). Asterisks indicate differences at $\mathrm{p}<0.001$ by Pearson's Chi-square (see text for further details).

Tabela 2. Resultados dos testes de germinação das espécies de semente mais abundantes encontradas em amostras fecais de Didelphis albiventris (Tratamento Fecal) e obtidas de frutos coletados na área de estudo (Controle). Asteriscos indicam diferenças significativas ( $\mathrm{p}<0.001)$ pelo teste de qui-quadrado de Pearson (mais detalhes no texto).

\begin{tabular}{lccccc}
\hline \multicolumn{1}{c}{ Plant species } & Life-form & \multicolumn{2}{c}{ Control } & & \multicolumn{2}{c}{ Fecal treatment } \\
\cline { 3 - 6 } & & Tested seeds & $\begin{array}{c}\text { Germination } \\
(\boldsymbol{\%})\end{array}$ & & $\begin{array}{c}\text { Tested seeds } \\
(\boldsymbol{\%})\end{array}$ \\
\hline $\begin{array}{l}\text { Cecropia } \\
\text { pachystachya } \text { Trécul }\end{array}$ & Tree & 257 & 87.94 & 261 & $68.20^{*}$ \\
Psidium guajava L. & Tree & 503 & 87.08 & 579 & $53.02^{*}$ \\
Passiflora edulis Sims & Liana & 306 & 4.90 & 412 & 5.34 \\
Piper amalago L. & Shrub & 423 & 74.70 & 507 & 71.01 \\
Morus nigra L. & Tree & 137 & 34.31 & 1,819 & $11.05^{*}$ \\
\hline
\end{tabular}


Table 3. Summary of results of odds ratio, indicating how many times a seed species from fresh fruit collected in the study area (Control) and found in D. albiventris' feces (Fecal Treatment) was more likely to germinate than the others.

Tabela 3. Sumário dos resultados da razão de odds indicando quantas vezes mais uma espécie de semente obtida de frutos frescos coletada na área de estudo (Controle) e encontradas nas fezes de D. albiventris (Tratamento Fecal) foi mais provável de germinar que as demais.

\begin{tabular}{|c|c|c|c|c|c|c|}
\hline \multirow[b]{2}{*}{ Species } & \multicolumn{3}{|c|}{ Control } & \multicolumn{3}{|c|}{ Fecal treatment } \\
\hline & $\begin{array}{c}\text { Times more } \\
\text { likely to } \\
\text { germinate }\end{array}$ & Than & $\begin{array}{l}\text { Odds } \\
\text { ratio }\end{array}$ & $\begin{array}{c}\text { Times more } \\
\text { likely to } \\
\text { germinate }\end{array}$ & Than & $\begin{array}{l}\text { Odds } \\
\text { ratio }\end{array}$ \\
\hline \multirow{4}{*}{$\begin{array}{l}\text { C. pachystachya } \\
\text { Trécul }\end{array}$} & 1.6 & P. guajava L. & 1.610 & & & \\
\hline & 15.9 & M. nigra $\mathrm{L}$. & 15.880 & & & \\
\hline & 179.5 & P. edulis Sims & 179.520 & 21.3 & P. edulis Sims & 0.047 \\
\hline & 3.1 & P. amalago L. & 3.130 & & & \\
\hline \multirow[t]{3}{*}{ P. guajava $\mathrm{L}$. } & 9.9 & M. nigra L. & 0.101 & & & \\
\hline & 111.1 & P. edulis Sims & 0.009 & 21.3 & P. edulis Sims & 0.047 \\
\hline & 2.0 & P. amalago $\mathrm{L}$. & 0.512 & & & \\
\hline \multirow[t]{3}{*}{ P. amalago $\mathrm{L}$. } & 5.0 & M. nigra L. & 0.200 & 2.0 & $\begin{array}{l}\text { C. pachystachya } \\
\text { Trécul }\end{array}$ & 2.030 \\
\hline & 50.0 & P. edulis Sims & 0.020 & 2.0 & M. nigra $\mathrm{L}$. & 2.030 \\
\hline & & & & 2.0 & P. guajava L. & 2.030 \\
\hline$M$. nigra $\mathrm{L}$. & 11.3 & P. edulis Sims & 11.310 & 21.3 & P. edulis Sims & 0.047 \\
\hline
\end{tabular}

1998). Although we have not found evidences of scarification, all of the seeds expelled by the white-eared opossum showed no pulp residuals at the same time that they were obviously involved by fecal matter.

Nevertheless, increasing germination rates is far from a general rule. Several intrinsic plant or frugivore variables can influence seed response to the passage through the digestive tract, such as fruit type, seed size, plant life-form, climatic zone where the plant occurs, habitat type, experimental condition, and frugivore taxa (Traveset \& Verdú 2002). Some of these variables can explain the observed differences on germination probabilities between and within the treatments of our tests. All the species had fleshy fruits with small seeds (up to $6.5 \mathrm{~mm}$ ), but different life-forms. Although generally germinating more than shrubs and herbs (Traveset 1998), we found that tree seeds were negatively affected by the gut treatment. Seed size may also interfere. Small seeds are consumed and transported by more species (small and larger marsupials, such as Micoureus spp. Lesson (1842) and Didelphis spp., respectively-Cáceres 2006), but are often retained for longer periods in the gut than larger seeds (e.g. Izhaki et al. 1995). Seed germination success decreases as retention time increases (Murray et al. 1994), which may explain low germination frequency of small consumed seeds (Traveset \& Verdú 2002) in this study. Germination tests conducted in Petri dishes (used in this study) are also intermediate to detect differences between natural habitats and greenhouses. Finally, birds (e.g. Meyer \& Witmer 1998) and bats (e.g. Mello et al. 2008) showed more positive effect on germination increase than reptiles or non-flying mammals, such as white-eared opossums.

The capacity of defecating viable seeds has been attributed to the white-eared opossum (Cáceres 2002). Didelphids mastication behavior (Monteiro-Filho 1987, Cáceres \& Monteiro-Filho 2000) and gastric acids rarely damage or affect the germination of defecated seeds (Cáceres \& Monteiro-Filho 2007). This viability is usually suggested by percentage of germination of seeds from feces (Cáceres \& Monteiro-Filho 2000, Cáceres 2002, 2004). If we utilize the categories of germination frequency used by Cáceres \& Monteiro-
Filho (2000), which consider low frequencies those until 33\%, the germination success of three of five species that we tested can be considered as moderate and high (cf. Grelle \& Garcia 1999, Cáceres \& Monteiro-Filho 2001, Cáceres 2002). However, the passage through the gut is not a pre requisite to germination success. A more careful look to the germination probabilities can reveal that, depending on the plant species, some ingested seeds may germinate less than the non-consumed ones.

On the other hand, fruit consumption and seed transport over great distances (e.g. Bodmer 1991) may be an important contribution to the increase in offspring survival (Jansen et al. 2008). Seeds fallen away from the high seed-density area near the parent trees have an increased chance for survival than seeds underneath them. This occurs due to the transfer of the offspring towards low predation and parasitism habitats ("predator escape" Janzen-Connell model, revised in Clark, D.A. \& Clark, D.B. 1984) and due to the conquest of microsites with greater establishment probability ("colonization", Howe \& Smallwood 1982). Opossums participate efficiently in this seeding process (e.g. Grelle \& Garcia 1999), because the excretion of seeds can occur during a period of 24 hours (Cáceres $\&$ Monteiro-Filho 2007). Since didelphids are more generalists in habitat occupation than other marsupials (e.g. Alho 2005), they are able to move more frequently in gaps and forest edges and, thus, defecating in more suitable microenvironments for pioneer plants (Medellín 1994, Cáceres et al. 1999, Cáceres 2006). Although the deposition site may not be favorable, the opossums contribute to the seed rain, which is vital for the soil seed bank. Since the majority of ingested seeds present dormancy (between six and 12 months Cáceres \& Monteiro-Filho 2007), the germination can be delayed (Cáceres 2002) to when more suitable conditions occur.

Moreover, as habitat generalists, D. albiventris and other opossums are able to live in high densities in small anthropized areas (Fonseca \& Robinson 1990) and to travel in fragmented landscapes (Pires et al. 2002). Thus, opossums may be able to transport seeds from forests to urban areas (e.g. Cordero \& Nicolas 1992, Cáceres \& Monteiro-Filho 2000, 2001), which make them important to 
the natural vegetal regeneration in a mosaic of habitats. As seed dispersers, they may contribute to alleviating the isolation of urban fragments, connecting the reminiscent forest and promoting gene flow (e.g. Mares \& Ernest 1995, Alho 2005). Therefore, opossums have been considered as management tools for forest regeneration (Cáceres \& Monteiro-Filho 2007).

In conclusion, because of their high vagility (e.g. Sunquist et al. 1987), the great variability of habitats that they inhabit, the fruits they consume, and their capability to transport seeds to appropriate microenvironments, $D$. albiventris and the other didelphids can be considered potential seed dispersers (Wiseman \& Hendrickson 1950, Medellín 1994, Cáceres et al. 1999, Cáceres \& Monteiro-Filho 2000). Even when not all ingested seeds germinate as frequently as the noningested ones, white-eared opossums feed especially on fruits with small seeds, which are swallowed intact and, depending on the species an expressive proportion of them (up to $71 \%$ ) remain viable after defecation. In disturbed forest fragments, vegetation regeneration is a critical process so the high tolerance to urbanization and the inclusion of plant typically of first-succession stages in its diet indicates the participation of this marsupial in the natural reforestation process. It is important that the vegetation renewal does not depend only on the specialist frugivores, which most times are absent in the forest fragments that must be restored (Estrada et al. 1984). The presence of generalist species of secondary environments becomes, therefore, valuable.

\section{Acknowledgements}

We are in debt with Jorge Tamashiro, who identified the most part of the seeds, André de Marco, who helped a lot sorting seeds and performing several germination tests, and João Semir, who identified some exsicates. We would like to thank Mariana Vedovello for separating animal vestiges from the samples; Clara Piccinini, Denise Gaspar, Michelle V.S. dos Santos, Camila Castilho, André de Marco for the help in the field; SUCEN team (Celso, Savina, Olga, Cida and Chico) for helping during captures; Michelle V. S. dos Santos for preparing the fecal samples; Hildete Prisco Pinheiro for help with the data analysis; José R. Trigo for important discussions; Michelle Borsz and Maria Cecília Magnani-Prince for proofreading the manuscript; and the two anonymous referees whose suggestions improved the article. M.C. received a SAE/UNICAMP research scholarship funding during field work season.

\section{References}

AGRESTI, A. 2002. Categorical Data Analysis. John Wiley \& Sons, Hoboken, $734 \mathrm{p}$.

ALÉSSIO, F.M., PONTES, A.R.M. \& SILVA, V.L. 2005. Feeding by Didelphis albiventris on tree gum in the Northeastern Atlantic Forest of Brazil. Mastozool. Neotrop. 12(1):53-56.

ALHO, C.J.R. 2005. Intergradation of habitats of non-volant small mammals in the patchy Cerrado landscape. Arq. Mus. Nac. 63(1):41-48.

ARAGONA, M. \& SETZ, E.Z.F. 2001. Diet of the maned wolf, Chrysocyon brachyurus (Mammalia: Canidae), during wet and dry seasons at Ibitipoca State Park, Brazil. J. Zool. 254(1):131-136.

ATRAMENTOWICZ, M. 1988. La frugivorie opportuniste de trios marsupiaux didelphidés de Guyane. Rev. Ecol. (Terre Vie) 43(1):47-57.

BARNEA, A., YOM-TOV, Y. \& FRIEDMAN, J. 1991. Does ingestion by birds affect seed germination? Funct. Ecol. 5(3):394-402.

BASCOMPTE, J. \& JORDANO, P. 2007. Plant-Animal mutualistic networks: the architecture of biodiversity. Ann. Rev. Ecol. Evol. Syst. 38:567-593.

BODMER, R.E. 1991. Strategies of seed dispersal and seed predation in Amazonian ungulates. Biotropica 23(3):255-261.
CÁCERES, N.C. \& MONTEIRO-FILHO, E.L.A. 2000. The commom opossum, Didelphis aurita, as a seed disperser of several plants in southern Brazil. Ciênc. Cult. 52:41-44.

CÁCERES, N.C. \& MONTEIRO-FILHO, E.L.A. 2001. Food habits, home range and activity of Didelphis aurita (Mammalia, Marsupialia) in a forest fragment of southern Brazil. Stud. Neotrop. Fauna Environ. 36(1):85-92.

CÁCERES, N.C. \& MONTEIRO-FILHO, E.L.A. 2007. Germination in Seed Species Ingested by Opossums: Implications for Seed Dispersal and Forest Conservation. Braz. Arch. Biol. Techol. 50(6):921-928.

CÁCERES, N.C. 2002. Food habits and seed dispersal by the white-eared opossum, Didelphis albiventris, in the southern Brazil. Stud. Neotrop. Fauna Environ. 37(2):97-104.

CÁCERES, N.C. 2004. Diet of three didelphid marsupials (Mammalia, Didelphimorphia) in southern Brazil. Mamm. Biol. 69(6):430-433.

CÁCERES, N.C. 2006. O papel de marsupiais na dispersão de sementes. In Os marsupiais do Brasil - Biología, Ecologia e Evolução (N.C. Cáceres \& E.L.A. Monteiro-Filho, eds.). Editora UFMS, Campo Grande, p. 255-269.

CÁCERES, N.C., DITTRICH, V.A.O. \& MONTEIRO-FILHO, E.L.A. 1999. Fruit consumption, distance of seed dispersal and germination of Solanaceous plants ingested by the common opossum (Didelphis aurita) in Southern Brazil. Rev. Ecol. (Terre Vie) 54(3):255-234.

CÁCERES, N.C., GHIZONI Jr., I.R. \& GRAIPEL, M.E. 2002. Diet of two marsupials, Lutreolina crassicaudata and Micoureus demerarae, in a coastal Atlantic Forest island of Brazil. Mammalia 66(3):331-340.

Centro de Pesquisas Meteorológicas e Climáticas Aplicadas à Agricultura - CEPAGRI. 2009. http://orion.cpa.unicamp.br/outras-informacoes/ clima-de-campinas.html (último acesso em 18/03/2009).

CERQUEIRA, R. 1985. The distribution of Didelphis in South America (Polyprotodontia, Didelphidae). J. Biogeogr. 12:135-145.

CHARLES-DOMINIQUE, P., ATRAMENTOWICZ, M., CHARLESDOMINIQUE, M., GÉRARD, H., HLADIK, A., HLADIK, C.M. \&PRÉVOST, M.F. 1981. Les mammiferes frugivores arboricoles nocturnes d'une Forest guyanaise: interrelations plantes-animaux. Rev. Ecol. (Terre Vie) 35:341-435.

CLARK, D.A. \& CLARK, D.B. 1984. Spacing dynamics of a tropical rainforest tree: evaluation of the Janzen-Connell model. Am. Nat. 124(6):769-788

CONNEL, J.H. 1971. On the role of natural enemies in prevent competitive exclusion in some marine animals and rainforest trees. In Dynamic of populations (P.J. Den Boer \& G.R. Gradwell, eds.). Pudoc, Wageningen, p. 289-312.

CORDERO, G.A. \& NICOLAS, R.A. 1992. Comparicion de la dieta del rabipelado (Didelphis marsupialis) em ambientes naturales y urbanos em Venezuela. Acta Cient. Venez. 43:159-163.

EMMONS, L.H. \& FEER, F. 1990. Neotropical Rainforest Mammal: a Field Guide. The University of Chicago Press, Chicago, 295p.

ESTRADA, A., COATES-ESTRADA, R. \& VÁZQUEZ-YANEZ, C. 1984. Observations on gruiting and dispersers of Cecropia obtusifolia at Los Tuxtlas, Mexico. Biotropica 16(4):315-318.

FACURE, K.G. \& GIARETTA, A.A. 1996. Food habits of carnivores in a coastal Atlantic Forest of southeastern Brazil. Mammalia 60(3):499-502.

FLEMING, T.H. \& SOSA, V.J. 1994. Effects of nectarivorous and frugivorous mammals on reproductive success of plants. J. Mamm. 75(4):845-851.

FONSECA, G.A.B. \& ROBINSON, J.G. 1990. Forest size and structure: competitive and predatory effects on small mammal communities. Biol. Conserv. 53(4):265-294.

FONSECA, G.A.B., REDFORD, K.H., PEREIRA, L.A. 1982. Notes on Didelphis albiventris (Lund, 1841) of Central Brazil. Ciênc. Cult. 34(10):1359-1362.

GRAIPEL, M.E., CHEREM, J.J., MONTEIRO-FILHO, E.L.A. \& GLOCK, L. 2006. Dinâmica populacional de marsupiais e roedores do Parque Municipal da Lagoa do Peri, Ilha de Santa Catarina, sul do Brasil. Mastozool. Neotrop. 13(1):31-49. 
GRELLE, C.E.V. \& GARCIA, Q.S. 1999. Potential dispersal of Cecropia hololeuca by the common opossum (Didelphis aurita) in Atlantic Forest, Southeastern Brazil. Rev. Ecol. (Terre Vie) 54:327-332.

HARPER, J.L. 1977. Population biology of plants. Academic Press, London, 892p.

HOWE, H.F. \& SMALLWOOD, J. 1982. Ecology of seed dispersal. Ann. Rev. Ecol. Evol. Syst. 13:201-228.

HOWE, H.F. 1993. Aspects of variation in a Neotropical seed dispersal system. Vegetatio 107/108:149-162.

HOWE, H.F., SCHUPP, E.W. \& WESTLEY, L.C. 1985. Early consequences of seed dispersal for a Neotropical tree (Virola surinamensis). Ecology 66(3):781-791.

IZHAKI, I., KORINE, C. \& ARAD, Z. 1995. The effect of bat (Rousettus aegyptiacus) dispersal on seed germination in eastern Mediterranean habitats. Oecologia 101(3):225-342.

JANSEN, P.A., BONGERS, F. \& VAN DER MEER, P.J. 2008. Is farther seed dispersal better? Spatial patterns of offspring mortality in three rainforest tree species with different dispersal abilities. Ecography 31(1):43-52.

JANZEN, D.H. 1970. Herbivores and the number of tree species in tropical forests. Am. Nat. 104(940):501-529.

JULIEN-LAFERRIÈRE, D. \& ATRAMENTOWICZ, M. 1990. Feeding and reproduction of three didelphid marsupials in two Neotropical forests (French Guiana). Biotropica 22(4):404-415.

LEINER, N.O. \& SILVA, W.R. 2007. Seasonal variation in the diet of the Brazilian slender opossum (Marmosps paulensis) in a montane Atlantic forest area, southeastern Brazil. J. Mamm. 88(1):158-164.

MARES, M.A. \& ERNEST, K.A. 1995. Population and community ecology of small mammals in a gallery forest of central Brazil. J. Mamm. 76(3):750-768

MARTINS, E.G. \& BONATO, V. 2004. On the diet of Gracilinanus microtarsus (Marsupialia: Didelphidae) in an Atlantic Rainforest fragment in southeastern Brazil. Mamm. Biol. 69(1):58-60.

MEDELLÍN, R.A. 1994. Seed dispersal of Cecropia obtusifolia by two species of opossums in the Selva Lacandona, Chiapas, Mexico. Biotropica 26(4):400-407.

MELLO, M.A.R., KALKO, E.K.V. \& SILVA, W.R. 2008. Movements of the bat Sturnira lilium and its role as a seed disperser of Solanaceae in the Brazilian Atlantic Forest. J. Trop. Ecol. 24(2):225-228.

MEYER, G.A. \& WITMER, M.G. 1998. Influence of seed processing by frugivorous birds on germination success of three North American shrubs. Am. Midl. Nat. 140(1):129-139.

MONTEIRO-FILHO, E.L.A. 1987. Biologia reprodutiva e espaço domiciliar de Didelphis albiventris em uma área perturbada na região de Campinas, Estado de São Paulo (Mammalia, Marsupialia). MSc. Thesis, Instituto de Biologia, Universidade Estadual de Campinas, Campinas.

MORELLATO, L.P.C. 1991. Estudo da fenologia de árvores, arbustos e lianas de uma floresta semidecidua do sudeste do Brasil. PhD Thesis, Instituto de Biologia, Universidade Estadual de Campinas, Campinas.

MURRAY, K.G., RUSSELL, S., PICONE, C.M., WINNETT-MURRAY, K., SHERWOOD, W. \& KUHLMANN, M.L. 1994. Fruit laxatives and seed passage rates in frugivores: consequences for plant reproductive success. Ecology 75(4):989-994.

OLIVEIRA, M.E. \& SANTORI, R.T. 1999. Predatory behavior of the opossum Didelphis albiventris on the pitviper Bothrops jararaca. Stud. Neotrop. Fauna Environ. 34(2):72-75.
PIRES, A.S., LIRA, P.K., FERNANDEZ, F.A.S., SCHITTINI, G.M. \& OLIVEIRA, L.C. 2002. Frequency of movements of small mammals among Atlantic Coastal Forest fragments in Brazil. Biol. Conserv. 108(2):229-237.

ROLLINS, D. \& CARROLL, J.P. 2001. Impacts of predation on northern bobwhite and scaled quail. Wildl. Soc. Bull. 29(1):39-51.

SANTIN, D.A. 1999. A vegetação remanescente do município de Campinas, São Paulo (SP): mapeamento, caracterização fisionômica e florística visando à conservação. $\mathrm{PhD}$ Thesis. Instituto de Biologia, Universidade Estadual de Campinas, Campinas.

SANTORI, R.T., ASTÚA DE MORAES, D. \& CERQUEIRA, R. 1995. Diet composition of Metachirus nudicaudatus and Didelphis aurita (Marsupialia: Didelphidaae) in southeastern Brazil. Mammalia 59(4):511-516.

SCHELHAS, J. \& GREENBERG, R. 1996. Introduction: The value of forest patches. In Forest Patches in Tropical Landscapes (J. Schelhas \& R. Goldberd, eds.). Island Press, Washington, p. 15-35.

SHAFER, C.L. 1990. Nature Reserves: Island Theory and Conservation Practice. Smithsonian Institution Press, Washington, 189p.

SMITHE, N. 1970. Relationships between fruiting seasons and seed dispersal methods in a Neotropical Forest. Am. Nat. 104(935):25-35.

STEINER, K.E. 1981. Nectarivory and potential pollination by a Neotropical marsupial. Ann. Mo. Bot. Gard. 68(1):505-513.

STREILEIN, K.E. 1982a. The ecology of small mammals in the semiarid Brazilian Caatinga. III. Climate and faunal composition. Ann. Carnegie Mus. 51:79-107.

STREILEIN, K.E. 1982b. Behavior, Ecology, and Distribution of South American Marsupials. In Mammalian Biology in South America (M.A Mares \& H.H. Genoways, eds.). University of Pittsburg, Linesville, p. 231-241.

SUNQUIST, M.E., AUSTAD, S.N. \& SUNQUIST, F. 1987. Movement patterns and home range patterns in the common opossum, Didelphis marsupialis. J. Mamm. 68(1):173-176.

TRAVESET, A. \& VERDÚ, M. 2002. A Meta-analysis of the effect of gut treatment on seed germination. In Seed Dispersal and Frugivory: Ecology, Evolution and Conservation (D.J. Levey, W.R. Silva \& M. Galetti, eds.) CAB International Publishing, Wallingford, p. 339-350.

TRAVESET, A. 1998. Effect of seed passage through vertebrate frugivores guts on germination: a review. Perspect. Plant Ecol. Evol. Syst. 1(1):151-190.

TRAVESET, A., BERMEJO, T. \& WILSON, M.F. 2001. Effect of manure composition on seedling emergence and growth of two commom shrub species os southeast Alaska. Plant Ecol. 155(1):29-34.

VAN DER PIJL, L. 1982. Principles of dispersal in higher plants. Springer Verlag, Berlin, 214p.

VÁZQUEZ-YANES, C. 1979. Estúdios sobre ecofisiología de la germinación em uma zona cálido-húmeda de México. In Regeneración de selvas (A. Gómez-Pompa, C. Vázquez-Yanes, S. Del Amo \& A. Butanda, eds.). Compania Editorial Continental SA, Mexico, p. 279-387.

WISEMAN, G.L. \& HENDRICKSON, G.O. 1950. Notes on the life history and ecology of the opossum in Southeast Iowa. J. Mamm. 31(3):331-337. 
